\title{
OP DIE GRENS VAN VAKWETENSKAP EN FILOSOFIE
}

Die begrip "grens" soos dit voorkom in die titel is vir meerdere uitleg vatbaar.

Eerstens sou dit kon dui op 'n onoorskreibare punt tussen die filosofie en die vakwetenskappe, so iets soos 'n grenspaal of baken, met ander woorde 'n punt van waterdigte skeiding tussen die domein van die filosofie en die vakwetenskappe. As 'n mens soms die dramatiese grensgevegte tussen die filosofie en die vakwetenskappe in die wetenskaplike literatuur beskou ' ' dan blyk dit kennelik noodsaaklik te wees om wel sodanige grens te stel, veral ten einde die gevaar van wetenskaplike terrorisme van die een of die ander kant die hoof te bied.

So word die begrip "grens" hier egter nie bedoel nie, hoewel erken moet word dat dit dikwels so funksioneer. ' $n$ Tweede betekenis van die begrip dui op die vae, diffuse miskien selfs onbegrensde tussengebied tussen die filosofie en die vakwetenskappe, so 'n groot wetenskaplike niemandsland waaraan weinig wetenskaplikes hulle wil waag omdat die veiligheid en die geborgenheid van die eie vakgebied ontbreek en hierdie taak op die grens altyd weer die gevaar inhou dat 'n mens deur die een of ander kant as onbeslae betrap sal word of as 'n renegaat beskou sal word. $U$ sal merk dat hierdie betekenis van die begrip "grens" veral hier nadere aandag sal geniet.

Maar daar is egter ook 'n derde betekenis van die begrip " "grens". Dit is 'n konnotasie wat betrekking het op beide filosofie en die vakwetenskappe en dit dui dan in besonder op die feit dat beide hierdie vorme van wetenskap be-grens is dit wil sê nie absoluut is nie en in die laaste instansie ook stuit voor die grense van menslike kenne en kundigheid.

Laat ons vervolgens egter eers 'n voorraadopname maak van die posisie van die filosofie te midde van die vakwetenska $a_{r}$.e aan die moderne universiteit.

\section{KRISIS VAN DIE MODERNE UNIVERSITEIT AKADEMIESE AARVERKALKING}

Verskillende denkers is dit eens dat die krisis van die moderne universiteit geleë is in die onsamehangende samebundeling van sterk gespesialiseerde en op beroepsopleiding gerigte vakwetenskappe. F L Polak ${ }^{2}$ ) praat in dié verband van die 
moderne universiteit as 'n "diplomafabriek" wat gestandardiseerde produkte moet lewer vir die "scientific society", waarmee die universiteit dan ook sy karakter as universitas prysgegee het.

$K J$ Popma praat in die verband van die fabrilisering van die universiteit waarmee bedoel word dat die tegniese, as menslike moontlikheid, sodanig oorspan word - ook in die wetenskaplike opleiding, dat dit lei tot die dehumanisering van die mens. Hierdie ontaarding van die universiteit word ook aangedui as die multiversiteit naamlik "een alleen nog administratief enigzins verbonden bundel van vakscholen ..."

Hierdie problematiek van die multiversiteit, die fabrilisering, oorspesialisasie en professionalisasie raak alle universiteite, miskien nog meer selfs in Suid-Afrika as in ander wêrelddele.

Dwarsdeur hierdie problematiek heen sny die hele krisis van die beginselgrondslag van die universiteit. "

'n Derde faset van hierdie krisis van die universiteit raak die vraagstuk van die gesprek tussen die verskillende wetenskaplike dissiplines.

In 1953 formuleer dr William S Carlson, ${ }^{6)}$ President van die State University of New York, voor 'n nasionale konferensie oor hoër onderwys die kern van die kulturele probleem van ons moderne wetenskapseeu en moderne universiteit as "aar verkalking" teweeggebring deur die afwesigheid van kommunikasie en gesprek tussen die verskillende kennisgebiede. So verkalk is die are van die moderne universiteit, sê hy, dat kommunikasie tussen basiese of suiwer wetenskappe en toegepaste wetenskappe haas nie-bestaan nie.

Meer as twintig jaar later wil dit voorkom asof hierdie akademiese aarverkalking nie afgeneem maar toegeneem het en asof die waterdigte afbakening van natuurwetenskappe en die sogenramde geesteswetenskappe en by name die skeiding tussen filosofie en vakwetenskappe nog sterker deurwerk as in vroeër dekades.

Hierteenoor blyk dit duidelik dat die komplekse moderne wêreld, wat mede deur die toedoen van die wetenskap tot stand gekom het, juis 'n behoefte het aan mense wat gevorm is deur ' $n$ kreatiewe interaksie van verskillende wetenskaplike dissiplines en wat in staat is om op grond daarvan gesaghebbend en kundig met die wêreld om hulle heen om te qaan. 
Waaraan sou die krisisverskynsels toegeskryf word? Talle faktore sou natuurlik in dié verband in aanmerking geneem moet word om 'n genuanseerde beeld te verkry maar miskien is die mees kenmerkende trek die gebrekkige realisering van die eenheid van die wetenskap binne die opset van die moderne universiteit. Die konsessie van die kant van die huidige wetenskapsbeoefening aan die eise van die praktiese beroepsopleiding het hierdie verbreking van die eenheid van die wetenskap besonder sterk in die hand gewerk.

Verset teen hierdie verskynsel is by voorbaat futiel. Gespesialiseerde beroepe het gekom om te bly en die daaraan korrelate spesialisasie van die wetenskap is ' $n$ verskynsel wat alleen maar verder sal toeneem.

Die spesialisasie van die wetenskappe is op sigself ' $n$ verblydende verskynsel omdat dit eintlik bewys is van feit dat die wetenskap ook beantwoord aan die veelsydige en komplekse aard van die deur God geskape werklikheid. Die spesialisering dreig egter om in spesialisme te ontaard wanneer in die eie spesialiseringsrigting nie rekenskap gegee word van die metodiese vakbegrensing van die eie vak nie. Hierdie voorkoming van die ontaarding/ontsporing van die spesialisasie tot atomistiese spesialisme, kan egter slegs teengewerk word vanuit ' $n$ verantwoording vanuit die grondslae van die wetenskappe self, met ander woorde vanuit 'n kyk op die verskeidenheid en die samehang van die werklikheid ${ }^{5)}$ en die wetenskap. 'n Gespesialiseerde vakstudent vorm intellektueel en kultureel 'n gevaar vir homself en vir die maatskappy, wanneer die universiteit nie minstens 'n poging aangewend het om sy denke te oefen insake die vorming van ' $n$ integrale lewenspersepktief, waarby inbegrepe is ' $n$ oortuiging met betrekking tot religieuse, politieke en etiese vraagstukke.

\section{FILOSOFIE: OORBODIGE LUUKSE?}

Die vraag ontstaan egter of die ideaal van die eenheid van die wetenskappe in die lig van hierdie ontwikkelinge nie as 'n onbereikbare lugspieëling gesien moet word nie. Miskien is juis hierdie af wesigheid van die eenheid van die wetenskappe die duidelikste simptoon van die stilswye tussen die vakwetenskappe onderling en die spraakloosheid tussen die filosofie en die vakwetenskappe. 'n Verskynsel wat hier te lande miskien veel groter afmetings aanneem as elders ter wêreld. 
Kyk 'n mens na die plek van die filosofie in die kurrikulum dan is dit duidelik dat dit maar net nog 'n moontlike keusevak in die ry van vakke is en, dat getakseer op sy brood-en botterwaarde dit maar taamlik onderaan die inkopielys van van die moderne Suid-Afrikaanse student staan. Dit blyk inderdaad 'n soort weelde-artikel te wees wat enkeles hulle veroorloof om in belang te stel wanneer die meer basiese behoeftes van vakkeuses met die oog op gerigte beroepsopleiding aan voldoen is.

Hierdie toedrag van sake is in die hand gewerk deur 'n soort opvatting van wetenskap as 'n grootheid wat primêr ten dienste van die gemeenskap aangewend moet word en waarvan die bydrae veral in nuttigheidswaarde tot uitdrukking moet kom.

Nou is dit voor-die-hand-liggend dat die moderne universiteit hom moeilik sal kan ontworstel aan hierdie tendens tot spesialisering en beroepsopleiding. Die raderwerk van die komplekse maatskappy van die toekoms met sy hoë eise van vaardigheid en gerigte beroepsbekwaamheid sal waarskynlik al heel gou vasdraai as dit alleen maar in die hande van die studeerkamergeleerde, ivoortoringgeleerde of laboratoriumgeleerde moet beland.

In die lig van die voorafgaande is dit feitlik vanselfsprekend dat wanneer die universiteit van die toekoms voor die probleem geplaas word van 'n keuse te maak met betrekking tot dissiplines wat as oorbodig beskou kan word, dan verg dit nie veel verbeelding om te profeteer dat die filosofie een van die eerste wetenskappe sal wees wat werkloos op die arbeidsmarkplein sal rondstaan nie.

Afgesien van die bruikbaarheid van die filosofie is daar egter ook nog 'n belangrike faset van die saak wat aandag behoort te geniet: Al sou menige vakwetenskaplike nog bereid wees om die filosofie as 'n soort weelde-artikel te duld, is daar weinig wat oortuig is dat die filosofie enige regstreekse verband hou met die beoefening van die vakwetenskappe of dat die vakwetenskappe enigsins in hulle ontwikkeling met die filosofie of met wysgerige veronderstellings moet rekening hou.

In hierdie hele miskenning van die filosofie is hy self ook nie onskuldig nie. Deur vele beoefenaars van hierdie wetenskap 
word die filosofie bedryf op 'n wyse wat die indruk wek dat die konkrete, alledaagse werklikheid nou net die een saak is waaroor dit nie in die filosofie gaan nie. Hierdie "werklikheidsureemde" beoefening van die filosofie is natuurlik allermins bevorderlik vir sy beeld na buite. Dit sou beslis nie in die lig hiervan vergesog wees om te praat van 'n kortsluiting in die relasie van die filosofie en die vakwetenskappe nie.

Waaraan moet hierdie vervreemding tussen vakwetenskappe en filosofie toegeskryf word? Meer nog, watter faktore werk eintlik hierdie duidelike miskenning en statusverlaging van die filosofie in die hand? Dit wil my tog voorkom asof ons hier beslis nog te make het met die deurwerking van reste van die tipies positiwistiese wetenskapsbeskouing waarin filosofie gereken word tot 'n soort metafisiese spekulasie, terwyl die vakwetenskappe alleen te make sou hê met die positiewe, eksakte feite van die sogenaamde empiriese werklikheid. In die mate waarin hierdie opvattinge deel uitmaak van ons akademiese erfenis is dit duidelik dat ons nog allermins met die neutrale wetenskapsbeoefening afgereken het.

Miskien is dit noodsaaklik om eers by wyse van 'n kort historiese terugblik te bepaal waar hierdie vervreemding tussen filosofie en vakwetenskappe onder andere vandaan kom en om te bepaal hoe die filosofie so in diskrediet geraak het, tot sy onlangse herverskyning as rewolusionêre maatskappyhervormer...

\section{HISTORIESE VOËLVLUG}

Aan die begin van die teoretiese besinning in die antieke Griekse kultuur het die filosofie uit die mitologie tot ontwikkeling gekom. Vanaf die voor-Sokratiese periode tot die einde van die Grieks-Romeinse beskawing, het die filosofie op sy eie bene gestaan as die moeder van feitlik alle gespesialiseerde teoretiese pogings. Vir bykans 'n duisend jaar gedurende die middeleeue was die filosofie beskou as die diensmaagd van die teologie. Aan die begin van die moderne tydperk het die rasionalisme bygedra tot die emansipasie van die filosofie van sowel die religie en die teologie - 'n emansipasie wat die idee van die outonomie van die wysgerige denke tot gevolg gehad het. 
Die opkoms van die positiwisme het tot 'n nuwe toedrag van sake gelei. Filofosie het die diensmaagd geword van die nuwe, opkomende vakwetenskappe, die natuurwetenskappe en die sogenaamde sosiale wetenskappe met hul nadruk op die waardevrye karakter van wetenskaplike ondersoek en akademiese onderrig.

Vandag bemerk ons 'n verstaanbare reaksie teen hierdie situasie. Hierdie reaksie het egter nie gevoer tot die herstel van die filosofie in sy regmatige plek aan die universiteit as die funderende interdissiplinêre band tussen die vakwetenskappe nie. Inteendeel - die ou dienskneggestalte verskyn in 'n nuwe gedaante: Fisolofie word nou die diensmaagd van die politiserende rigting, so sterk verdedig deur die voorstanders van die "kritiese universiteit". ") Hierdie is tans een van die hoofrigtinge van die Europese en Amerikaanse universiteite. Teenoor hierdie posisie bemerk ons dat die Anglo-Saksiese filosofie nog steeds sy neutrale en waardevrye karakter verdedig deur die reduksie van die filosofie tot 'n taalsuiweringsapparaat. ${ }^{8)}$

Die kernprobleem is uiteraard wat presies nou die funksie en rol van die filosofie aan die universiteit is of behoort te wees en indien daarop ' $n$ antwoord geformuleer kan word, moet natuurlik weë en middele gesoek word om binne die praktiese opset van universitêre studie daaraan uitdrukking te gee. Hierdie funksie en taak sal natuurlik ook geformuleer moet word teen die agtergrond van die heersende krisis van die universiteit.

\section{HOE INTERFAKULTÊR IS DIE WYSBEGEERTE?}

Wanneer die taak van die universiteit saam met Ortega $Y$ Gasset geformuleer word as: die oordrag van kultuur, die opleiding vir verskillende beroepe en wetenskaplike navorsing en die opleiding van nuwe wetenskaplikes ${ }^{9}$ ), dan is dit duidelik dat veral die eersgenoemde en laasgenoemde funksie, naamlik die inlywing van die student in 'n kultuur of die kulturele vorming van die student aan die universiteit asook die ruimer wetenskaplike vorming deur die toedoen van bogenoemde krisis ernstig in gedrang kom. Juis hierdie funksie word deur die fabrilisering, oorspesialisasie en professionalisasie van die universiteit ernstig belemmer. 
In die verband wys $\mathrm{K}$ Jaspers daarop dat die universiteit deur middel van sy benaming aandui dat dit gaan om 'n opleiding en vorming van ' $n$ universele aard $^{10}{ }^{0}$ ) en dat alle deelgebiede van die wetenskap wat bestudeer en onderrig word een toets moet kan deurstaan naamlik dat dit 'n duidelike relasie met die geheel moet vertoon. ${ }^{11}$ )

Hierdie filosofie moet eintlik in en deur die vakwetenskappe beoefen word en gestalte kry. 'n Aparte leerstoel vir die filosofie is slegs regverdigbaar om pedagogiese en administratiewe redes, so meen hy.

Dit is duidelik dat die problematiese posisie van die filosofie binne die universiteit veral in die hand gewerk word deur die feit dat die eenheidsperspektief - in Jaspers se terme "the philosophical point of view ...", 2) moeilik gestalte kry binne die opset van die moderne universiteit. Dit wil voorkom asof die universiteit deur sy opset van navorsing en onderrig die wetenskap so gefragmentariseer het dat die geheelbeeld, so noodsaaklik vir vorming in die breedste sin van die woord, verlore geraak het.

Hoe moet hierdie lakune opgevul word?

Verskillende poginge is reeds aangewend, ook hier te lande. ${ }^{13)}$

In die meeste van hierdie poginge word die oplossing gesoek in 'n soort eksterne toegoeging tot die bestaande kurrikulum ten einde daardeur 'n "breër algemene vorming" van die student te bewerkstellig. Dat die opstel van 'n dergelike kurrikulum, wat in staat sou wees om al die ergste leemtes van die multiversiteit te vul, 'n onbegonne taak is, behoef weinig betoog. Veel meer as 'n tydelike noodverband vir die krisis van die universiteit kan dit nie wees nie. As dergelyke ensiklopediese bindmiddele vir die snel-desintegrerende akademiese gebou is ook reeds afsonderlike kursusse in die filosofie en wetenskapsleer aangebied. Ook die kursus in Interfakultêre Wysbegeerte aan die $\mathrm{P} \mathrm{U}$ vir $\mathrm{C} \mathrm{H} \mathrm{O}$ het langsamerhand onder meer in hierdie rigting ontwikkel. Dat 'n dergelike kursus beperkinge het, is duidelik. Dit is nie 'n substituut vir intergraad-Christelike wetenskapsbeoefening nie: dit mag nie 'n Christelike wetenskapsmodel wees wat eenvoudig soos 'n kitsproduk met vakwetenskaplike kookwater vermeng kan word om dan Christelike wetenskap as resultaat op te lewer nie. 
Dit is uit die voorafgaande duidelik dat die filosofie wel deeglik die wetenskap is waardeur die eenheidsperspektief sigbaar word en wat ook daartoe meewerk dat die student ruimer vorming ondergaan en perspektief verkry. Dit is egter ook duidelik dat die wyse waarop hierdie wetenskap meestal aan die universiteit gestruktureer word, naamlik as 'n opsionele keusevak naas ander keusevakke of die organisasie binne ' $n$ de - part - ement nou juis hierdie interfakultêre karakter van die filosofie as dissipline misken. In so 'n kurrikulum- struktuur sal die Wysbegeerte-kursus vermy word deur die deursnee-student, eenvoudig omdat die student nie bevoeg is om die vraagstukke wat in die filosofie aan die orde gestel word, te hanteer nie. Hy sien nie die verband tussen sy eie akademiese en beroepsopleiding en die filosofie nie en beskou derhalwe 'n dergelike wysgerige kursus as 'n vermorsing van tyd. Die nadelige gevolge van hierdie opsionele benadering is duidelik. Weinig akademici is werklik geinteresseerd om insig in die grondslae van sy eie vakwetenskaplike rigting te verkry en nog minder is in die reël geinteresseerd in die interrelasie van sy eie besondere dissipline met ander dissiplines of ' $n$ teoretiese insig in die samehang daarvan met ander dissiplines binne die hele werklikheid.

Die moderne ontwikkelinge binne die filosofie self het hierdie probleme eintlik net vererger. Wanneer filosofie sy naelstring met die samehangende, gestruktureerde werklikheid en die wetenskappe aangaande die werklikheid op hierdie wyse deursny, is hy ook nie in staat om die vakwetenskappe te integreer of saam te bind binne die huidige konsep van die multiversiteit nie. In die lig hiervan kan hy dan ook nie sy funksie vervul van die eksplisering van die grondslae en die wysgerige probleme van die onderskeie vakwetenskappe nie. Vandaar dan ook die afwesigheid van die gestruktureerde sinvolle wisselwerking tussen filosofie en die vakwetenskappe.

Teenoor hierdie pertinente onderwaardering van die filosofie en die kortsluiting tussen vakwetenskappe en filosofie, blyk dit dus noodsaaklik te wees om 'n ander faset te beklemtoon naamlik juis die interafhanklikheid van vakwetenskap en filosofie wat veral daarin tot uitdrukking kom dat die filosofie tot taak het die fundering van die wetenskappe as teorie aangaande die werklikheid, terwyl die vakwetenskappe op hulle beurt mede tot taak het die kritiese besinning oor dit 
waarmee hulle hulleself besig hou. Nou is die interessante hiervan dat die filosofie slegs filosofie kan wees in die ware sin van die woord as dit sy verantwoording van die samehang van die werklikheid, aanpak in aansluiting by die vakwetenskappe, terwyl die vakwetenskappe, as wetenskappe aangaande 'n faset van die werklikheid, slegs vakwetenskap kan wees in die ware sin van die woord as hulle dié faset van die werklikheid besien vanuit 'n geheelperspektief wat implisiet aanwesig is en liefs ook eksplisiet verantwoord moet word. Hieraan moet natuurlik volledigheidshalwe toegevoeg word dat beide filosofie en vakwetenskappe as wetenskappe aangaande die deur God geskape werklikheid, alleen tot volle kennis en insig kan kom na die mate dat die aspek en die samehang teoretiese uitdrukking is van 'n werklikheidsvisie wat deur die Woord van God - die geskape Woord (skepping), Vleesgeworde Woord (Jesus Christus) en die Skrifwoord geslyp is.

Wat is dan nou, meer pertinent geformuleer, die funksie van die (vak-?) filosofie? Miskien is die eenvoudigste antwoord die radikale funksie van die filosofie, ${ }^{14}$ ) dit wil sê deurvra terugvra tot op die wortels of grondslae van die denke en bestaan van die mens en wêreld en daarmee saam ook die grondslae van die vakwetenskappe.

Die blote feit dat sowel sosiale- as natuurwetenskappe $\mathrm{e}^{16}$ ) volop werk met duidelik wysgerige en interfakultêre problematiek, is meer as voldoende aanduiding dat hierdie aangeleentheid nie maar lukraak en terloops in die loop van die bestudering en die onderrig aangeraak mag word nie. Dit moet eksplisiet aandag geniet binne die vakwetenskap of die filosofie en moontlik liefs binne 'n vakfilosofie (wat prakties by enigeen van die twee wetenskappe tuisgebring kan word).

\section{WAT IS GRONDSLAE-ONDERSOEK?}

Die tradisionele opvatting van die waardevryheid van die wetenskap het natuurlik die idee van die vooronderstellingsloosheid of waardevryheid van die wetenskap ingeburger.

Die bewering dat die wetenskap vry sou wees van vooronderstellings is eintlik ' $n$ onmoontlike eis. Wanneer niks vooronderstel is nie, kan 'n mens ook niks ken nie - nie in die daaglikse ervaring nie, nog minder in die wetenskap. ${ }^{16)}$ Ook 
Jaspers erken dat ' $n$ vooronderstellingslose wetenskap nie kan bestaan nie. In die eerste plek veronderstel die wetenskap sy eie wenslikheid, tweedens word in die wetenskap ten minste die gehoorsaamheid aan die reëls van die logika veronderstel, terwyl die wetenskap sekerlik ook impliseer dat dit gerig en gelei word deur 'n bepaalde regulatiewe idee aangaande die werklikheid. Juis hierdie veronderstellings vorm die konteks en raamwerk waarbinne ontdekking en voortgang van die wetenskap moontlik word. ${ }^{17)}$ Die gedagte dat die wetenskap gebonde is aan kennisvooronderstellings kom reeds by Aristoteles voor. ${ }^{18}$ ) 'n Willekeurige greep uit 'n vakwetenskap sal voldoende wees om hierdie stelling te illustreer:

Hans Morgenthau wys daarop dat die student in die staatsleer en van die politiek op geen ander wyse die politieke toneel kan benader as vanuit baie duidelik vooropgesette vooronderstellings nie. ${ }^{19)}$ Ten opsigte van die staatsleer stel hy dit soos volg: Die student van die politiek kyk na die politiese verskynsels vanuit 'n perspektief wat gedetermineer word deur sy filosofie. Of hy dit nou wil erken of nie, hy is staatsfilosoof voordat hy ' $n$ politikoloog is. Dit is slegs binne so ' $n$ wysgerige raamwerk dat ' $n$ empiriese raamwerk van politiese navorsing sinvol en vrugbaar kan wees. ${ }^{20}$ ) Hierdie stelling geld vir elke wetenskap.

U sal besef dat, as die afwesigheid van vooronderstellings inderdaad die eis van wetenskaplikheid sou wees, dan is dit problematies om te stel dat dit die taak van die folosofie is om hierdie vooronderstellinge van die vakwetenskappe te ondersoek. Die integrasie van die wetenskap word deur die wysbegeerte bereik nie deur die totalisering van alle deelkennis nie, maar deur die grondslae-ondersoek wat alle spesialisasie moontlik maak en ook onderling laat saamhang. Hierdie integrasie moet juis deur-die differensiasie geskied en dit neem juis 'n aanvang waar, binne elke vakwetenskap, die onderskeid tussen hoofsaak en bysaak wysgerig verantwoord word. U sal merk daar is nou van die begrip ,spesialisasie" oorgestap op die begrip "differensiasie".

Teenoor die eensydige en oppervlakkige eenheidstrewe as reaksie op die ver deurgevoerde spesialisasie sal ons die ware integrasie deur differensiasie moet verdedig, waardeur dus 
sowel die eiesoortigheid van die eie vakgebied en die samehang van hierdie vakgebied met andere, binne die gesigsveld kom. ${ }^{21)}$

Wat opmerklik is, is dat die vakwetenskappe in hierdie proses van verantwoording oor hulle grense al spoedig stuit op gemeenskaplike probleme van feitlik alle wetenskappe. In dié verband kom dan probleme soos kenteoretiese, metodologiese, antropologiese en wetenskapsteoretiese vrae na vore.

Dat hierdie werklike en ideale eenheid van die wetenskappe nie so 'n gemaklik bereikbare saak is nie, behoef natuurlik weinig betoog. Nie slegs is die taal van die vakwetenskaplike en wysgeer dikwels vir mekaar haas onverstaanbaar nie, maar wanneer die woord "wysgeer" val, word al gou besef dat daar net soveel wysgerige sisteme as wysgere bestaan.

Hierdie saak het natuurlik ook sy problematiese kant vir die voorstander van Christelike wetenskap, want die keuse lê dikwels tussen skoolvorming rondom een sisteem óf fragmentarisering ooreenkomstig 'n groot verskeidenheid van Christelik-wysgerige sisteme. Die saak word verder bemoeilik deur die afwesigheid van lewende wisselwerking en kontak tussen filosofie en vakwetenskappe sodat die vak wetenskappe reeds, in die afwesigheid van die filosofie as gespreksgenoot, al gewoond geraak het daaraan om sy eie wysgerige problematiek te ignoreer of te ontken dat dit bestaan.

\section{FILOSOFIE AS VERBINDINGSOFFISIER}

Nou moet daar geen misverstand bestaan oor hoe die verhouding tussen vakwetenskap en filosofie nou eintlik behoort te wees nie. Dit mag nie so geinterpreteer word asof die filosofie alleen oor die finale antwoorde beskik en die vakwetenskappe in afhanklikheid van die filosofie moet wag op 'n soort sistematiese wysgerig openbaringsmodel wat dan as 'n skema van interpretasie van die werklikheid deur die vakwetenskappe gebruik moet word nie. Ook die filosofie is aangewys op die ontwikkeling en ontplooiing van die kennis van die vakwetenskappe wat telkens 'n bepaalde kant van die werklikheid verder uitdiep. En beide filosofie en vakwetenskappe is afhanklik van die openbaring van God. 
Waarvoor ons veel sterker oog sal moet kry is die feit dat vir die behandeling van alle wysgerige kwessies wat ' $n$ bepaalde vakwetenskap of groep vakwetenskappe raak, wysgere nodig is wat die besondere vakwetenskappe en veral hulle grondslae ken. ${ }^{2} 2$ ) Dit is natuurlik nie moontlik dat elke filosoof op die hoogte is van alle vakwetenskappe nie, maar tog 'n redelike eis dat binne ' $n$ werkgemeenskap van filosowe kenners verteenwoordig is, sodat die wysgeer as't ware op die grens van die vakwetenskap, dit wil sê sonder om noodwendig aan die vakwetensskaplike ondersoek mee te doen - as ' $n$ "tolk" optree ten einde die vakwetenskaplike problematiek in wysgerige taal te "vertaal" of die wysgerige insig deur te gee aan die vakwetenskaplikes. Van Melsen ${ }^{23}$ ) praat in dié verband van die filosofie as 'n "verbindings-officier" - 'n beeld wat $\mathrm{m}$ i goed inpas met die term "grens" soos gebruik in die titel.

$\mathrm{U}$ sal merk dat die beeld van die relasie tussen filosofie en vakwetenskappe nie soseer aan die model van 'n bowe- en onderbou beantwoord nie, maar veeleer aan dié van 'n sirkel waarvan die filosofie die sentrum uitmaak en die vakwetenskappe hulle weer verder na die periferie van die sirkel bevind ... tog kan die sirkel slegs sirkel wees as dit 'n middelpunt het en kan dit ook net sirkel wees as dit 'n omtrek het.

Juis hierdie sentrale gerigtheid van die filosofie ${ }^{24}$ ) is die kenmerkende van die filosofie as wetenskap.

Dit het teen hierdie tyd reeds baie duidelik geblyk dat die departementalistiese opvatting van die filosofie as vak naasandere ten nouste saamhang met ' $n$ bepaalde wetenskapsleer. Die probleem waarom dit dus gaan is die definiëring van die aard van die wetenskap op só ' $n$ wyse dat dit moontlik is om uitdrukking te gee aan die sentrale funksie van die filosofie.

Indien hierdie siening van die taak van die filosofie en die relasie van filosofie en vakwetenskappe juis is, is dit voor-diehand-liggend dat die tyd ryp is vir 'n ontwikkelingsfase in hierdie onderlinge relasie, een waarin die gedagte van interdissiplinêre gesprek en grondslae-ondersoek struktureel moontlik gemaak word. Hiertoe sou die huidige opset van die departement Interfakultêre Wysbegeerte aan die $\mathrm{P} U$ vir $\mathrm{C} \mathrm{HO}$ natuurlik 'n belangrike wegbereider kon wees. 
Net so belangrik is egter die daarstelling van kanale waarbinne die wisselwerking tussen filosofie en vakwetenskappe kan plaasvind en waarvan die student ook die vrugte kan pluk. Sistematiese uitbou van vakfilosofieë sou al 'n belangrike begin in hierdie verband wees. Net so belangrik is egter ook die integrasie van ' $n$ kursus in wetenskapsleer in die studiepakket van studente in alle fakulteite.

Die belangrike vraag wat egter nou na vore tree is dié bepaling van wie verantwoordelik is vir die reeds genoemde grondslae-ondersoek. Is dit die taak van die filosofie om die vakwetenskaplike grondslae te ekspliseer of is dit die verantwoordelikheid van die vakwetenskappe self? Verskillende antwoorde is in die loop van die tyd reeds op hierdie vraag geformuleer. ${ }^{25)}$ Agter hierdie vraag skuil natuurlik die moeilike probleem van die rol van die filosofie in die wetenskapsbeoefening en die verhouding tussen vakwetenskap en filosofie. 'n Vraag waarteenoor reeds gedeeltelik hierbo 'n antwoord geformuleer is. Ten einde ' $n$ onvrugbare toutrekkery in die verband te voorkom lyk dit my noodsaaklik dat daar daadwerklik gewerk moet word aan die uitbou van die voorgestelde interdissiplinêre vakfilosofiese departemente waarbinne hierdie noodsaaklike wisselwerking tussen filosofie en die vakwetenskappe gestalte kan kry en waarbinne dit moontlik is om gemaklik oor die grense van vakwetenskap en filosofie heen in twee rigtings te beweeg. Hierdeur word'n vrugbare verbinding van die wysgerige begrip met wetenskaplike deskundigheid op ' $n$ bepaalde vakgebied moontlik gemaak. Sou hierdie ontwikkeling beteken dat die kursus in Interfakultêre Wysbegeerte oorbodig word? Dit wil my nie so voorkom nie - inteendeel. Deur'n dergelyke opset, meen ek, sal die kursus eers tot sy volle reg en ontplooiing kom en veel sterker aan sy doel beantwoord.

Indien die verband tussen die vakwetenskaplike kennis enersyds en die filosofie andersyds nie duidelik word vir die student wat gevorm moet word nie, dan is hierdie kennis ook maar net nog 'n brokstuk of fragment wat naas ander fragmente in die wetenskaplike sosatie geryg word. Dit is dan ook verstaanbaar dat die student moeite ondervind om die sin van dergelyke studie te verstaan.

Duidelik is dit egter dat hierdie vorming, hetsy in die filosofie of die vakwetenskappe of vakfilosofie, slegs waarlik 
vormend kan wees na die mate dat dit gedra word deur'n dosentekorps wat self hierdie verbande duidelik sien. Hierdie is ' $n$ gemeenskapstaak - 'n taak vir die universitas ${ }^{26}$ ) in die oorspronklike sin van die woord - en nie 'n taak vir enkelinge nie.

Wil die filosofie egter hierdie kardinale rol binne die universitêre bestel vervul, dan mag dit geen bykomende addendum wees in die gebou van die wetenskappe nie, maar moet dit juis intrinsiek betrokke wees in die gehele wetenskaplike bedryf. Die fundamentele probleem waarom dit dus gaan, is die versoening van ' $n$ bemiddelende rol van die filosofie en sy integrasiefunksie binne 'n universitêre opset wat organisatories en akademies weinig ruimte bied vir 'n dergelike vak met 'n dergelike funksie. Dat die filosofie 'n soort redmiddel vir al die $\mathrm{kwale}$ van die moderne ontbindende universiteit sou kon wees, is natuurlik 'n illusie - die aard van die gebrek aan eenheid van die wetenskappe is te kompleks en vertoon te veel fasette om met so ' $n$ simplistiese probleemoplossing gediend te wees. ${ }^{27}$ ) Veel sterker vorweging verdien die gedagte van die ontwikkeling van 'n sentrale interfakulteit op Europese model, desnoods meerdere dergelike fakulteite binne een universiteit.

\section{PRAKTIESE VOORSTELLE}

Binne sodanige sentrale interfakulteit sou die filosofie as dissipline ' $n$ tuiste kon vind, maar so 'n fakulteit sou ook voorts tot taak hê die daarstelling van kanale vir die bevordering van interdissiplinêre kontak en studie en desnoods uie toekenning van grade op grond van interdissiplinêre en interfakultêre studie op die grensgebied van filosofie en vakwetenskap. Hiernaas sou dit ook wenslik wees dat in elke fakulteit 'n sentrale interdissiplinêre department tot stand gebring word waarbinne die betrokke vakfilosofie of vakfilosofieë 'n tuiste vind, sodat langs hierdie weg op natuurlike wyse reg aan die wysgerige problematiek van die betrokke vakke kan geskied.

'n Verdere rol van die filosofie in die wetenskappe sou kon wees via die geskiedenis van die vakwetenskappe. In dié verband word gedink aan die belangrike publikasie van Hooykaas, ${ }^{28}$ ) waarin langs die weg van die geskiedenis van die natuurwetenskappe duidelik aangetoon word watter belangrike rol wysgerige en ander vooronderstellings in die wetenskap speel. 
Iets wat ook in ons eie universitêre bestel nog weinig aandag ontvang het is multi-dissiplinêre navorsing en die samestelling van multi-dissiplinêre kursusse, dit wil sê sodat dit byvoorbeeld in die praktyk vir ' $n$ student in die ingenieurswese moontlik sou wees om met gemak wysbegeerte as vak of minstens 'n vakfilosofiese dissipline in 'n kursus in te sluit. Ook in hierdie verband sou die organisatoriese opset van 'n sentrale interfakulteit die kanaal daar kon stel waardeur sodanige studie en navorsing moontlik gemaak word.

In dié verband moet die belangrikheid van die raakvlakke van wetenskap en die verskillende ander sektore van die samelewing asook die relasie wetenskap-geloof of wetenskapsetiek beslis nie buite rekening gelaat word nie.

Die vraag kan ontstaan of die taak van die filosofie in sy verhouding tot die vakwetenskappe soos dit hier ontwikkel is, nie dalk ' $n$ bietjie te pretensieus is nie.

Is dit werlik vir een wetenskap beskore om as 'n soort grenswagter diens te doen met die uitdruklike veronderstelling dat hy alleen hierdie funksie kan vervul?

Dit is inderdaad ' $n$ aanmatigende stelling, behalwe wanneer dit gaan om 'n wysbegeerte wat hom laat begrens deur die diepste en hoogste wysheid - die vrese van die Here. Laat ons hieroor geen illusies koester nie, as ons hierdie grondslae van ons vakwetenskaplike werk nie krities ondersoek nie en as ons nie bereid is om daarteenoor teties en prinsipieel vanuit 'n eie Christelik-wysgerige visie stelling in te neem nie, dan laat ons willens en wetens die teoretiese onkruid op die wetenskaplike akkers toe. Argwaan teenoor enige reeds geformuleerde Christelik-wysgerige sisteem mag ons nie weerhou van hierdie belangrike taak nie.

Ook ten opsigte van die filosofie as wetonskaplike en sistematiese vormgewing van 'n kyk op die lewe en wêreld moet die gelowige wetenskaplikes krities staan - ook daarin, kan selfs wanneer dit as 'n Christelike filosofie aangedien word, ontsporinge voorkom ... on tsporinge wat ook - net soos die van die vakwetenskappe - alleen in die juiste perspektief kom wanneer dit gesien word in die lig van die derde betekenis van die begrip "grens" soos hierbo bespreek, naamlik die horison of die grens van die menslike denke en wetenskap. 'n Grens gestel deur die grense van ons menslike intellektuele 
bevattingsvermoë, maar ook 'n grens gestel deur God se openbaring aan ons in Sy skepping en in Sy Woord.

Wanneer die filosofie hom met die genoemde grensprobleme besig hou, dan blyk al spoedig die fundamentele behoefte aan wysheid in die Bybelse sin van die woord, by sowel die filosofie en die vakwetenskappe.

Miskien is dit juis in ons huidige tyd met sy enorme oorskatting van die mag en moontlikhede van die wetenskap noodsaaklik om te erken dat beide filosofie en vakwetenskappe begrensd is - begrens veral in die moontlikhede om sin en doel en rigting aan die menslike lewe te gee. ${ }^{29}$ ). En hierdie grense geld net so vir die grense van Christelike wetenskapsbeoefening ... ook dit is ' $n$ middel tot 'n doel, geen doel op sigself nie. Hoe noodsaaklik en belangrik die beoefening van die wetenskap in die integraal-Christelike sin van die woord ookal mag wees, dit is geen substituut vir die radikale en fundamentele rol van die geloof in omvattende sin in die menslike lewe nie.

M Elaine Botha

P U vir C H O 


\section{VERWYSINGS}

1. Vgl Piaget, J, Main trends in psychology. London 1970. p 10 e v.

2. Vgl POLAK F L, De toekomst is verleden tijd, dl II. Utrecht, 1955, p 172 e v asook Popma, K J, De Universiteit. Idee en practijk. Amsterdam, 1969, p 9, 10, 11.

3. Op cit, p 9, 10.

4. VAN RIESSEN $H$, The university and its basis. Ontario, 1963. p 15.

5. WIENER, P P, (Red) Voorwoord, In Readings in the philosophy of science. Introduction to the foundations and cultural aspects of sciences. New York, 1953. p v.

6. LOUET-FEISSER, $\mathrm{J} J$, Wetenschap in toga. Utrecht, $1962, \mathrm{p} 33$.

7. Vgl o a Regtien, Ton, Universiteit in opstand. Amsterdam, 1969 asook Peper, Bram en Wolters, Willem, De lastige universiteit, Rotterdam, 1970.

8. DU PLESSIS, P G W, Gevraagde universiteit. Publikasiereeks nr 3, University of P E, 1967, p 9, 10 asook Louët-F eisser, J J, Student en wisjbegeerte. Een perspectief op de interfacultaire functie van de filosofie in de universiteit. Assen, 1969, p 14-16 e v.

9. ORTEGA Y GASSET, T, Mission of the university. London, $1946, \mathrm{p} 48$.

10. JASPERS, KARL. The idea of the university. London, 1960. p 59.

11. Jaspers. Loc cit.

12 Ibid, $p 60$.

13. Vgl. Du Plessis, P G W, Gevraagde universiteit.

14. LOUET-REISSER, Student en wijsbegeerte, $p 12$.

15. $\mathrm{Vgl}$ in diê verband: Haldane. Loc cit; Piaget, Loc cit asook Morgenthau, Hans J, Understanding politics In The decline of democratic politics. Chicago, 1962, pp 16-52.

16. KUYPERS, K, Het begrip hypothesis (vooronderstelling, grondslag) en de bepaling van de verhouding tussen vakwetenschap en filosofie. In: Verspreide geschriften, dl II. Wetencschap en kunde. Assen, 1968, p 228.

17. JASPERS. Op cit p 35.

18. Analytica posteriora, 71 a $1-2$

19. Op cit, p 31 .

20. Morgenthau skryf: "We only call attention to the basic proposition that in politics empirical enquiry without a philosophic framework must needs be blind, as political philosophy without empirical verification must needs be wholly speculative." Sien op cit, p 32.

21. LOUET-FEISSER, J J, De integratie der wetenschap. In Louët-Feisser e a (samestellers) De Christen-Academicus en de wetenschap. Amsterdam. 1949, p 9 e v.

22. VAN MELSEN, A G M, Eenheid en verscheidenheid der wetenschap. Nijmegen, 1945, p 13.

23. Id.

24. POS, H J, Filosofie der wetenschappen. Derde druk. Amhem, 1947, p 102. 
25. KUYPERS, op cit, p 212.

26. JASPERS, op cit, p 59.

27. DU PLESSIS, op cit, p 44.

28. HOOYKAAS, $R$, Religion and the rise of modern science.

Edinburgh, 1972.

29. JASPERS, op cit, p 30. 